\title{
Development of a Religious Based Coaching Model to Address Problems Faced by Prisoners at First Class Detention Center Makassar
}

\author{
Muhammadong, Abdul Hadis \& Eva Meizara Puspita Dewi \\ Makassar State of University \\ Muhamadong74@gmail.com
}

\begin{abstract}
The purpose of this research is to overcome the problems faced by prisoners in Class 1 Makassar Detention Center so that the inmates will not tend to do anarchic actions and devote themselves when in the middle of society. The target of this research to be achieved is the inmates can change their mindset in a positive direction so that they are no longer subject but will be a motivator to others so that their behavior is always oriented to worship. The method used in this research is model developed by Borg and Gall in 1993 which modified by research team into 6 stages, namely needs and planning analysis, model development, product validation / expert test, product trial, product revision, final product. The results show that religious-based modeling should be developed in Makassar Class 1 Detention House by looking for other formats that have not been developed yet. Among them is the development of the Qur'an memorizing agency. This institution is very urgent to be applied so that inmates in their community can become the memorizers of the Qur'an and Imam for the community. This institution turns out to be very in demand Prisoners because they can form their mental oriented emotional intelligence. Among the dynamically changing behavior of the institution's establishment is the attitude of response to fellow Prisoners so that among others they want to always make improvements give each other message of kinesssand not affected the criminal behavior offered by other inmates. Another formation that needs to be developed in Class 1 Makassar Detention Center is the establishment of an institution of remembrance. The institution aims to form the character of a Prisoner oriented to spiritual intelligence. They doa and lot of zikir in order to get closer to Allah SWT which has been less implemented in his life. The significant impact of the change from the institution's establishment that the Prisoners are constructed with gentle behavior so that they can adapt their fellow Prisoners and can easily convey the divine messages exchanging massage to the truth.
\end{abstract}

Keywords: Guidance, based, religious, prisoners

\section{INTRODUCTION}

According to law no. 12 of 1995 states that prisoners are prisoners who underwent criminal disappearance of independence in penitentiary (penitentiary), ie a person convicted under a court decision that has obtained legal force. Adami chazawi said that inmates are troubled people who are separated from society to learn socially well, it is further said that inmates are human beings like other human beings simply because they violate existing legal norms, then separated by judges to serve sentences.

(Uppe, 1996) Inmates are persons or groups who are serving punishment as a result of negative acts committed contrary to legal norms, social norms, religious norms, and customs and cultures prevailing in society. The prisoners are punished according to the decisions set by the judges in the court, based on the considerations that are to be used in deciding a punishment to a violator of the law, for example based on the severity of the violation of the law committed by the prisoner, according to a police report based on the results of the investigation and research on crime scene (crime scene), based on prosecutors' demands as public prosecutors, and based on the opinions of defendants or attorneys of the defendant.

(Syeikh Abdul Qadir Jaelani, 2002) In general, inmates at the local, regional, national, and international level, prisoners are more prisoners in prison in prison, because they have violated laws and regulations (umara), clerics or religious leaders, community leaders, and other parties who determine the policies, decisions, and rules of the game.

(Mattulada, 1997) in the life of society, nation, and state. Violation of law and rule, for example in the form of: pass drug and drug dot, consuming drugs, sexual harassment, raping, stealing, picking alias grabbing, mugged and threaten someone or groups with weapons or other types of sharp objects, cheating, robbing, extortion, and other criminal acts, which are categorized as violations of social norms, legal norms, religious norms, customs, and cultures that are respected and respected by a society, as a guide in behaving in society.

(Hadis, 2014). Prisoners built in prisons, including prisoners guided in class 1 prison of makassar city, generally violate laws or rules that apply in the community, caused by many factors that lie behind them. The factors that trigger and cause a person or group of prisoners to violate the law and rules that apply in the community, is due to the pressure and economic pressure, weak faith and piety that is owned by a person or group of people. In addition, the broken home factor causing the child or family member to "broken home" to seek outflow outside the home in the form of a negative act or behavior that violates the law, rules and norms prevailing in society, in mimicking a negative model on various broadcast shows or movies on television, movie shows in cinema, movie shows on CD (compact disc), DVD movies, and the like that contain the content of violent scenes and freedom of association between men and women which leads to free sex, is also a factor causing a person or group of people to violate the norms of law, religious norms, social norms, culture and customs prevailing in society. even worse than that, there is a movie show that demonstrates LGBT culture (lesbian, gay, bisexual, and transgender) which has been far from the teachings of Islam, also trigger and cause a person or a group of people to violate the norms of law, religious norms, social norms, cultures and customs prevailing in society.

(Abu Hamid, 1978) Religious modeling is a solution to solve the problems faced by Prisoners in Makassar. The model should be packed properly so they will not get bored with it. Many models of coaching have been applied, but the model sometimes saturates the prisoners. It turns out that it is not the physical guidance that chills the Prisoners, but more than that, they want the peace of mind so they can 
feel the immediate meaning of life. This is the background of this research conducted at the Class 1 Makassar Detention Center. So that the model of religious-based development is in accordance with the word of Allah Surah Yunus verse 57, that is (oh man, indeed has come to you the Qur'an ' which contains the teachings, the antidote for liver disease, guidance and grace for the believers).

\section{METHOD}

The type of research is the development of religiousbased coaching model. It is hoped that this research can find a model of guidance on inmates at First Class Detention Center Makassar. The development research is defined as a systematic assessment of the design, development, evaluation of programs, and processes in order to meet the criteria of validity, practicality, and effectiveness.

This research adopted the development of model proposed by Borg \& Gall which modified by research team into 6 stages, namely stage 1. Need assessmen (analys needs). At this stage a preliminary study is conducted with preparation or field survey, looking for information on the condition and activities of narapida.2. Planning; which is included in this step is to formulate the objectives of the religious-based model of coaching in an effort to solve the problem of narapida; 3. Development, in this stage is to develop the initial product including preparing the materials of religious formation in the House of Detainees, 4. Validation of the initial product, which includes in this stage is to test / test experts on products developed in order to provide input for product improvement; 5. Field trials, this stage is conducted to test products developed both small and large scale, 6 . Revised products, this stage is done to improve the product developed to get the standard model.

\section{RESULT}

The results of the study indicate that the model of guidance based on religious therapy needs to be developed by looking for the format that has not been developed in the First Class Detention House Makassar. Among them is the development of the Qur'an memorizing agency. This institution is very urgent for prisoners when out of prisons, they can develop their talents as a memorizing of the Qur'an. In order to overcome the problems faced by the Prisoners, it is necessary the institution of remembrance. The institute aims to shape the character of inmaates, so that they can improve their personalities while in the House of Detention and not easily affected by other inmates. In order to develop religious insight, a pesantren institution is established so that inmates can conduct religious studies. So the inmate is no longer an object but can be a subject when out of the House of Detention.

The therapeutic model developed at the Detention Center helps the inmate in solving the problems faced. because they do more activities in the mosque. Activities carried out in the mosque are almost said to be very solid. among them Tadabbur Al-Qur'an, in order to be able to inspire inmates to fill their spare time. In this tadabbur, the prisoners also melakuka activities Tahsin Al-Qur'an so they can understand the meaning and teachings of the Qur'an. The function of this tahsin, basically teaches them to understand the Qur'an with good reading as well as they are taught to memorize it. In Tadabbur Al-Qur'an activities, the inmates develop it by reading Yaasin, zikir and prayer.

Among the flagship programs developed at the Class 1 Makassar Detention Center is the coaching of Tahfidz AlQur'an. This activity gets its own attention among inmates who dilaksanaka every day after sunset prayer to enter time Isya '. Inmates perform the activities of the Qur'an by one day one verse method which is more emphasized in verse and short surah. So they have exprience in memorizing Qur'anic verses and can be used while in the community. In addition, the prisoners are provided with counseling held by the House Class 1 Makassar in collaboration with the Ministry of Religious Affairs of Makassar. This activity is done by lecture method then Q \& A by the participants related to the experience of the prisoner, even to his personal problems.

\section{DISCUSSION}

In the early stages, researchers explain about the development of a model of coaching with a religious-based therapy. This model helps the inmates in an effort to address the problems they face so that they are no longer treated as objects but more can be subject. The presence of this model gives hope to fresh air to the inmates in order to shape their character. The model of coaching based on religious therapy is more in demand by inmates because it is very touching their life issues, not even a few of them are very antusia in following the model of coaching.

Religious-based coaching is a concrete step done by researchers so that prisoners can benefit directly that life inside the House of Prison is very different from the life experienced when in the middle of society. So they no longer want to commit crimes that can harm themselves and their families.

In addition, with a religion-based guidance-based approach, the inmates more closely attach themselves to their god as the creator. They are aware of the meaning of life in the world if only melakoni himself as a lover of the world but far from religion will dapa harm themselves.

In the Class 1 Makassar Detention Center, there are many models of guidance done by inmates, but religious therapy-based coaching is highly prized by them. Because the implementation is very easy to do them and not boring, the practice is very simple. What is needed of them is a sincere commitment and intention in running this model. So the inmates who have been engaged in this work and are accustomed to in practice are always motivated to repeat.

\section{CONCLUSION}

Inmates is a group of people whose lives are much different from ordinary people who can breathe free air. Freedom Prisoners are limited by various dimensions of both time and place. This restriction is what makes them saturated and not a few who commit a crime even though they are already in a cell of detention. Therefore, various ways that can be done in order to make him aware. Religious therapy-based coaching is a supporting factor in awakening Prisoners in Class 1 Makassar Detention Center. So that they are no longer as a conscious party but more than that they can awaken themselves. Religious therapybased coaching takes much of their time in the mosque in 
the context of mental coaching. Religious-based coaching is very situational because it must adapt to other activities outside the mosque's schedule. Religious therapy-based coaching is very helpful to them because it can awaken from various situations. So that they no longer act as subjects but can be objects that benefit themselves and others. Religious-based coaching not only focuses on one center but does a combination of coaching that has been applied.

\section{BIBLIOGRAPHY}

\section{Al-Qur'an Al-Karim}

Departemen Agama RI, 1995, Al-Qur'an dan Terjemahnya (Cet. I; Toha Putra: Semarang.
Hamid, Abu. 1978.Sistem Pesantren Madrasah dan Pesantren di Sulawesi Selatan.: Fakultas Sastra UNHAS. Ujung Pandang.

Hadis, Abdul, 2014. Dampak Negatif Teknologi Informasi Komunikasi terhadap Remaja. Makassar: Pustaka Pribadi.

Jaelani, Syeikh Abdul Qadir. 2002. Rahasia Sufi, Terjemahan. Abdul Majid Hj.Khatib, Cet. III. Pustaka Sufi. Yogyakarta.

Uppe, M. 1996. Perbuatan Pidana dalam Pandangan Hukum Nasional. Malang: Pustaka Pribadi. 